\title{
Will heavy metals in the soils of newly submerged areas threaten the water quality of Danjiangkou Reservoir, China?
}

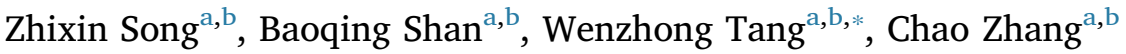 \\ a State Key Laboratory of Environmental Aquatic Chemistry, Research Center for Eco-Environmental Sciences, Chinese Academy of Sciences, Beijing 100085, China \\ b University of Chinese Academy of Science, Beijing 100049, China
}

\section{A R T I C L E I N F O}

\section{Keywords:}

Danjiangkou Reservoir

Newly submerged area

Heavy metal

Risk assessment

\begin{abstract}
A B S T R A C T
Soil heavy metal contents were measured in newly submerged areas of the Danjiangkou Reservoir, China. We aimed to determine the heavy metal distribution in this area and the associated ecological risk. Most of these heavy metal contents (except $\mathrm{Pb}$ and $\mathrm{Mn}$ ) suggest enrichment compared with the background values of soils from Henan Province, especially As and Cd with mean geo-accumulation index $\left(I_{\text {geo }}\right)$ values of 0.84 and 0.54 . The spatial analysis results indicated that the highest heavy metal contents were distributed in the arable soils above $160 \mathrm{~m}$ elevation, whereas low heavy metal contents were observed under other land-use types above $160 \mathrm{~m}$ elevation. According to $I_{\text {geo }}$ and EF values, Cd was the major heavy metal contaminant in the newly submerged area, $\mathrm{Cr}, \mathrm{Pb}$ and $\mathrm{Mn}$ mainly originated from natural geochemical sources. In contrast, $\mathrm{Ni}, \mathrm{Cd}, \mathrm{As}, \mathrm{Cu}, \mathrm{and} \mathrm{Zn}$ mainly originated from anthropogenic sources. Evaluation using the potential ecological risk (PER) method indicated that PER of individual elements were low in the studied soils, and the comprehensive PER index was at a moderate level, indicating heavy metals in the soils of newly submerged areas may not threaten the water quality of Danjiangkou Reservoir, especially in winter.
\end{abstract}

\section{Introduction}

Heavy metal pollution is found worldwide; human activities such as fossil fuel combustion, urban-industrial expansion and agricultural practices influence heavy metal contents in soils, especially in developing countries (Gao et al., 2013; Hu et al., 2014; Tang et al., 2014). Moreover, many studies have demonstrated that heavy metal contamination can cause substantial long-term negative effects on ecosystems (Campanha et al., 2012). Heavy metal pollution in soils may harm human health through the food chain. In addition, heavy metal contamination can lead to further deterioration in the quality of the air and water environments. As a result of new infrastructure from water conservancy projects, a large new area of soil has become submerged in water. This represents a potential ecological risk from previous human production activities causing new contamination problems under an artificially changed landscape.

The South-to-North Water Diversion Project was to transfer water from Danjiangkou Reservoir to North China for irrigation, domestic and industrial use. After completion of this project, the Danjiangkou Reservoir storage of water surface elevation increased from 157 to $170 \mathrm{~m}$, and capacity increased from 17.45 to 29.05 billion $\mathrm{m}^{3}$. The area of the newly submerged land is $307.70 \mathrm{~km}^{2}$, the heavy metals accumulated within this submerged area could be released into the water under appropriate conditions, affecting the water quality. Previous studies have focused on the water quality of the reservoir and mainly concentrated on the reservoir upstream catchment areas, or on the ecological environment (Wang et al., 2015; Zhang et al., 2015, Lei et al., 2015, Zeng et al., 2015). However, very little is known about the distribution characteristics and risk assessment of heavy metals in the submerged areas of the reservoir, particularly the newly submerged areas (Boughriet et al., 2007, Cheng and Hu 2010). Therefore, it is necessary to study the distribution, pollution, and ecological risk of heavy metals in the soils of newly submerged area.

This research focuses on the newly submerged area of Danjiangkou Reservoir in Henan Province. We analyzed $\mathrm{Ni}, \mathrm{Cu}, \mathrm{Zn}, \mathrm{Cd}, \mathrm{Pb}, \mathrm{As}, \mathrm{Mn}$, and $\mathrm{Cr}$ contents and distribution characteristics, and used the geological accumulation index $\left(I_{g e o}\right)$ and the potential ecological risk (PER) to evaluate heavy metals pollution and the potential ecological risk. Ultimately, the current research is important in developing water management and conservation strategies of the reservoir for water security in the South-to-North Water Diversion Project.

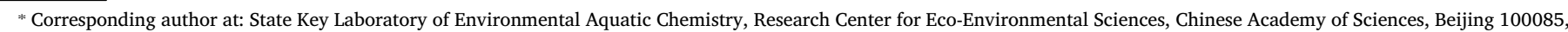
PR China.

E-mail addresses: bqshan@rcees.ac.cn (B. Shan), wztang@rcees.ac.cn (W. Tang). 


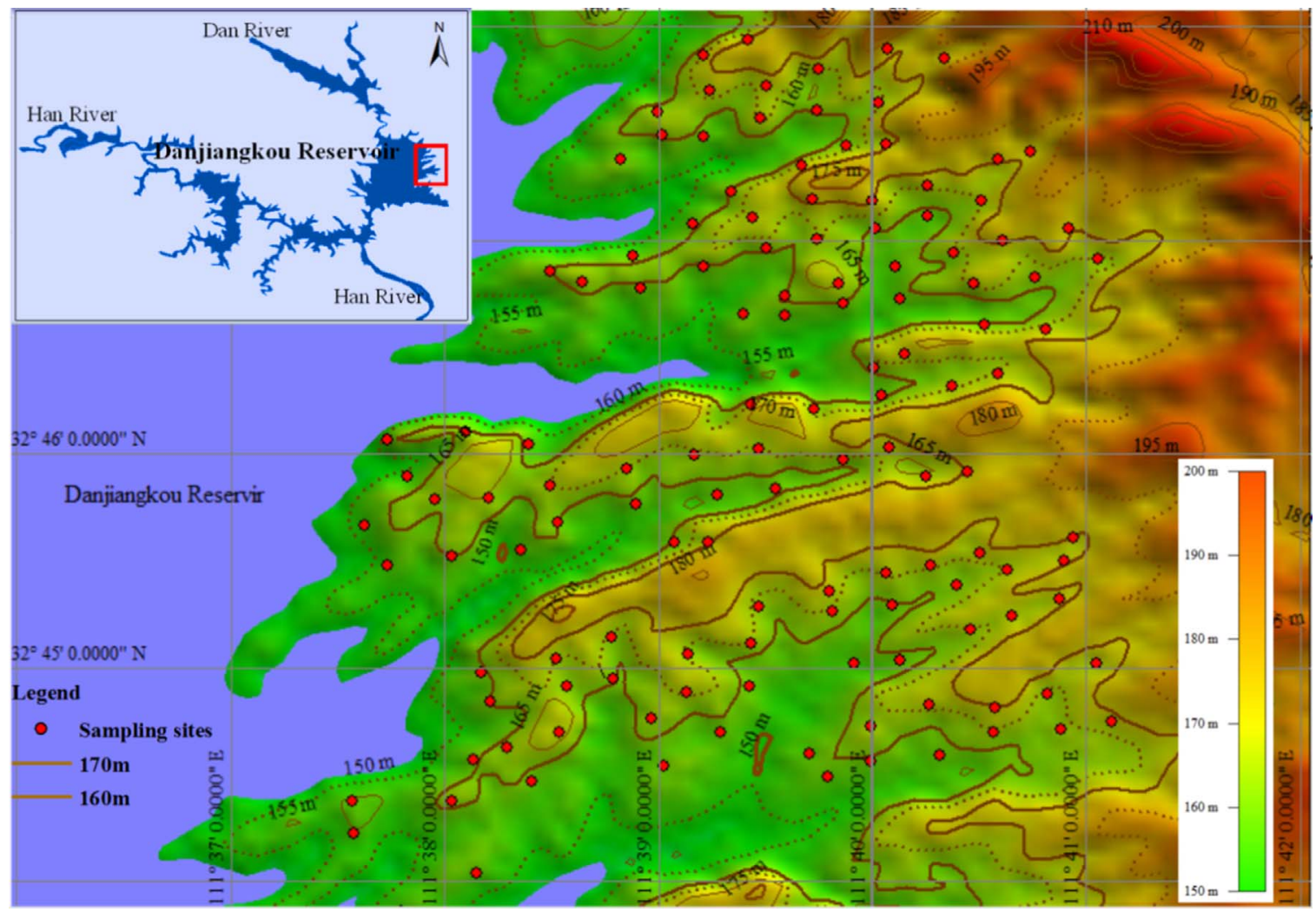

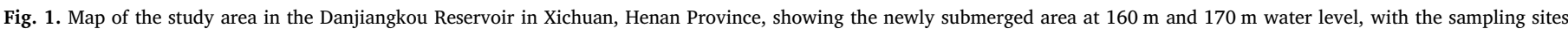
indicated $(\mathrm{n}=92)$.

\section{Materials and methods}

\subsection{Study area}

The Danjiangkou Reservoir $\left(32^{\circ} 360^{\prime}-33^{\circ} 480^{\prime} \mathrm{N}, 110^{\circ} 590^{\prime}-111^{\circ} 490^{\prime} \mathrm{E}\right)$ is located at the juncture of Hubei and Henan provinces, China (Fig. 1). The reservoir was built in the 1970s and the water surface area was $745 \mathrm{~km}^{2}$. The soils are mainly yellow and brown, and mean $\mathrm{pH}$ is 7.40 . The area has a subtropical monsoon humid climate with an average annual temperature of $15.80^{\circ} \mathrm{C}$ and average annual precipitation of $804.30 \mathrm{~mm}$. Rainfall is abundant but seasonally variable, with the main precipitation events occurring in July and September.

The first phase of the Danjiangkou Reservoir project was completed in 1973 and the normal storage level is $157 \mathrm{~m}$. After the 2nd phase of the water diversion in 2014, the storage level was increased to $170 \mathrm{~m}$ and generating a newly submerged area was $307.70 \mathrm{~km}^{2}$, a large area of arable land in Henan was submerged. The periodic water scheduling occurs from May 1 to June 21 every year. During this period, the water surface elevation is gradually reduced from 170 to $160 \mathrm{~m}$ in summer. On August 21, the reservoir is allowed to gradually fill with water up to an elevation of $163.50 \mathrm{~m}$. After October 1, the reservoir is gradually filled to the normal storage elevation of $170 \mathrm{~m}$. The water level fluctuates between approximately 160 and $170 \mathrm{~m}$, generating up to $10 \mathrm{~m}$ variation in the submerged land zone.

The newly submerged area in Xichuan was as the study area (Fig. 1). Basic information of the distribution of sampling sites and the number of sampling sites is provided in Table S1.

\subsection{Sample collection and analysis}

Based on the high-resolution remote-sensing images of the Danjiangkou Reservoir area, we divided the newly submerged area into several investigation units. We designed the scheme according to the sample sites uniformity, representativeness, and percentage of different land-use types (arable land, woodland, grassland, bare land and other land uses) across the newly submerged area. We used GPS and soil sampling in each survey unit (Fig. 1), and collected a total of 92 samples. Sampling sites were distributed evenly across the newly submerged area of Xichuan County, covering the different land-use types and elevations. In July 2014, the soil samples were collected, the methods was detailed description in the previous paper (Zhu et al., 2015; Tang et al., 2015).

Soil $\mathrm{pH}$, soil organic matter (SOM) in sediment, the grain-size distribution, and analysis of $\mathrm{Fe}, \mathrm{Al}, \mathrm{Ca}, \mathrm{Mn}, \mathrm{Ni}, \mathrm{Cu}, \mathrm{Zn}, \mathrm{Cd}, \mathrm{Pb}, \mathrm{As}$ and $\mathrm{Cr}$ contents was detailed description in the previous paper (Zhu et al., 2015; Tang et al., 2015).

\subsection{Pollution, risk and toxicity assessment}

The sources and factors influencing heavy metals contents in the studied soils were assessed and Enrichment Factor (EF) of metals were calculated (Selvaraj et al., 2004; Bian et al., 2014). The pollution and risk assessment of heavy metals in the soils were assessed using $I_{\text {geo }}$ (Müller, 1969; Sakellari et al., 2011; Tang et al., 2015), Pollution Load Index (PLI), and PER (Tomlinson et al., 1980; Yu et al., 2001). In addition, soil quality guidelines and $Q_{m-P E C}$ were used to evaluate soil ecological toxicity, and to predict whether surface soils contain heavy metals levels that are toxic to benthic organisms (Håkanson, 1980). These methods are described in detail in the supplementary materials (Table S2).

\subsection{Statistical analysis}

The distribution of the sampling sites was set using ArcGIS 9.3 and the data were analyzed with SPSS 16.0. Pearson correlation coefficients, plot the data and other statistical analysis were detailed description by the previous paper (Zhu et al., 2015; Tang et al., 2015). 
Table 1

Physical and chemical characteristics of soils in the newly submerged area (SD: Standard deviation; $\mathrm{n}=92$ )

\begin{tabular}{lllll}
\hline Item & Range & Mean & Median & SD \\
\hline $\mathrm{SOM} \mathrm{(g/kg)}$ & $7.65-20.83$ & 12.57 & 11.43 & 6.54 \\
$\mathrm{Al} \mathrm{(g/kg)}$ & $45.76-79.76$ & 62.02 & 63.21 & 13.71 \\
$\mathrm{Fe} \mathrm{(g/kg)}$ & $28.93-44.78$ & 36.34 & 34.87 & 4.46 \\
$\mathrm{Mn}(\mathrm{mg} / \mathrm{kg})$ & $457.89-723.46$ & 572.88 & 560.43 & 134.93 \\
$\mathrm{Ca}(\mathrm{g} / \mathrm{kg})$ & $5.24-45.32$ & 16.61 & 10.54 & 11.95 \\
$\mathrm{Clay}(\%)$ & $3.52-12.98$ & 9.51 & 11.23 & 7.36 \\
Silt (\%) & $51.96-71.93$ & 63.96 & 65.32 & 26.31 \\
Sand (\%) & $18.23-35.82$ & 26.54 & 28.14 & 27.17 \\
\hline
\end{tabular}

\section{Results and discussion}

\subsection{Soil characteristics in the newly submerged area}

General physical and chemical characteristics of the soils in the newly submerged area of the Danjiangkou Reservoir are presented in Table 1 . The SOM content was range 7.65-20.83 g/kg, and the standard deviation was 6.54, the SOM contents in grassland soils were high. Silt was the major particle fraction (51.96-71.93\%) and the lowest silt fractions were found in sampling sites from bare land. Clay was the minor fraction and ranged from $2.69 \%$ to $12.98 \%$.

\subsection{Heavy metals distribution in the surface soils}

The Ni, $\mathrm{Cu}, \mathrm{Zn}, \mathrm{As}, \mathrm{Cd}, \mathrm{Pb}, \mathrm{Mn}$, and $\mathrm{Cr}$ contents in soils of the newly submerged area in the Danjiangkou Reservoir were detected, and compared with the state soil environment quality standard and the Henan soil background value (Table S3). The metal contents had different spatial and distribution trends due to the varied sources from different production activities on different types of land (Li et al., 2015). The heavy metals contents in soils of the newly submerged area were higher than the Henan soil background value. As shown in Table 2, the $\mathrm{Zn}$ and $\mathrm{Pb}$ contents were higher than the contents of other metals (conforming to the first grade of the state soil environmental quality standard). $95.50 \%$ of the total of 92 soil samples for $\mathrm{Cr}$ were conforming to the first grade of the state soil environmental quality standard and As contents all belonged to the second grade of the state soil environmental quality standard.

Meanwhile, $87.80 \%$ of the soil samples for $\mathrm{Pb}$ were higher than the background value of Henan Province. For Mn, 68.18\% were higher, $46.96 \%$ for $\mathrm{Cr}$, and all others were below $20 \%$. As, Ni, Cu, Zn and Cd are thus the major pollutants in soil from the newly submerged area of the Danjiangkou Reservoir and may pose health risks to the residents of the region and to water-receiving areas. The soil samples contained

Table 2

Distribution of heavy metals contents in surface soils from the newly submerged area (SD, standard deviation; GB (\%), the percentage of samples conforming to National Standard of Soil Grades I, II, and III; and BV, the percentage of samples less than the background value of Henan; $\mathrm{n}=92$ ).

\begin{tabular}{|c|c|c|c|c|c|c|c|}
\hline \multirow[b]{2}{*}{ Level } & \multirow[t]{2}{*}{ Range $(\mathrm{mg} / \mathrm{kg})$} & \multirow{2}{*}{$\begin{array}{l}\text { Mean } \\
\text { (mg/ } \\
\mathrm{kg})\end{array}$} & \multirow[t]{2}{*}{ SD } & \multicolumn{3}{|l|}{ GB (\%) } & \multirow{2}{*}{$\begin{array}{l}\text { BV (\%) } \\
<\mathrm{BV}\end{array}$} \\
\hline & & & & $<\mathrm{I}$ & II-III & $>$ III & \\
\hline $\mathbf{N i}$ & $26.5-54.4$ & 38.33 & 7.68 & $86.50 \%$ & $9 \%$ & $4.50 \%$ & $4.50 \%$ \\
\hline $\mathrm{Cu}$ & $17.03-52.4$ & 27.76 & 8.43 & $92.50 \%$ & $7.50 \%$ & 0 & $18.18 \%$ \\
\hline $\mathrm{Zn}$ & $49.4-83.1$ & 63.92 & 29.52 & $100 \%$ & 0 & 0 & $15.10 \%$ \\
\hline As & $14.8-48.7$ & 24.28 & 7.38 & $9 \%$ & $88.50 \%$ & $1.50 \%$ & $0.00 \%$ \\
\hline Cd & $0.02-1.17$ & 0.27 & 0.32 & $89 \%$ & $6 \%$ & $5 \%$ & $17.50 \%$ \\
\hline $\mathbf{P b}$ & $5.31-66.94$ & 18.72 & 14.9 & $100 \%$ & 0 & 0 & $87.80 \%$ \\
\hline Mn & $423.01-773.84$ & 519.90 & 33.40 & - & - & - & $68.18 \%$ \\
\hline $\mathrm{Cr}$ & $42.96-86.93$ & 60.81 & 14.40 & $95.50 \%$ & $4.50 \%$ & 0 & $46.96 \%$ \\
\hline
\end{tabular}

high mean As content $(24.28 \mathrm{mg} / \mathrm{kg})$, whereas the mean content of As background value of soils from Henan Province is $9.8 \mathrm{mg} / \mathrm{kg}$. It can be assumed that the metal contents in the newly submerged area of the Danjiangkou Reservoir were due to the accumulation of agricultural production from the use of chemical and fertilizers in the area.

The $\mathrm{Ni}, \mathrm{Cu}, \mathrm{Zn}, \mathrm{As}, \mathrm{Cd}, \mathrm{Pb}, \mathrm{Mn}$, and $\mathrm{Cr}$ contents were differently distributed under different land-use types in the newly submerged area (Fig. 2(a)). The mean Ni content value in arable land was $44.80 \mathrm{mg} / \mathrm{kg}$, higher than those of other land-use types, and the standard deviation value was 6.50. It was indicated that the arable land was mainly affected by anthropogenic sources. The mean $\mathrm{Zn}$ and $\mathrm{Pb}$ contents belonged to the first grade of the state soil environment quality standard; however, they were higher in construction land and wasteland, whereas arable land, woodland and grassland were relatively lower. The mean contents values of $\mathrm{Mn}$ and $\mathrm{Cr}$ followed a similar decreasing sequence as follows: arable land $>$ woodland $>$ grassland $>$ bare land $>$ other land uses. Both $\mathrm{Mn}$ and $\mathrm{Cr}$ were slightly affected by anthropogenic sources. The mean contents of $\mathrm{Cu}$, As and $\mathrm{Cd}$ in arable land were strongly affected by anthropogenic sources (such as agricultural fertilizer and pesticide) and were higher than other land-use types. This was especially the case for As and Cd contents. According to the background values of soils from Henan Province, $\mathrm{Ni}, \mathrm{Cu}$, As, and $\mathrm{Cd}$ were the main pollution elements in the arable lands. The arable land might be associated with considerable PER during a water storage period, and it is important to explore distribution characteristics of $\mathrm{Ni}, \mathrm{Cu}, \mathrm{As}$, and $\mathrm{Cd}$ in the arable land.

In addition, we were able to identify the high-risk zone in the newly submerged area that should be given more attention, especially in areas that were previously under arable land use. The high-risk land-use types can be easily identified from the spatial distribution of heavy metals. Besides, we positioned the sampling sites at different elevations to allow an accurate examination of pollution across the arable areas. The four heavy metals with the higher accumulation levels $\mathrm{(Ni}, \mathrm{Cu}$, As, and Cd) were analyzed at different elevation, as shown in Fig. 2(b). The Ni, $\mathrm{Cu}, \mathrm{As}$, and $\mathrm{Cd}$ contents increased with elevation. For example, the mean Ni content values in arable land at 150-160, 160-165, 165-170, and $170-180 \mathrm{~m}$ elevation were $34.06,38.49,40.70$, and $40.91 \mathrm{mg} / \mathrm{kg}$, respectively. The mean $\mathrm{Cu}$ and $\mathrm{Cd}$ content values were 21.03 and $0.118 \mathrm{mg} / \mathrm{kg}$ at $150-160 \mathrm{~m}$ elevation of arable land, respectively, and mean $\mathrm{Cu}$ content value was more than $31.35 \mathrm{mg} / \mathrm{kg}$ above $160 \mathrm{~m}$ elevation, whereas the mean Cd content value was more than $0.123 \mathrm{mg} / \mathrm{kg}$ above $165 \mathrm{~m}$ elevation. The variation in the mean As content value was small in arable land below $170 \mathrm{~m}$ elevation, and higher at above $170 \mathrm{~m}$ elevation.

On the whole, the arable land above $160 \mathrm{~m}$ elevation was the main pollution risk area, and there was almost no pollution apparent in arable land below $160 \mathrm{~m}$ elevation. That may be the local farmers reduced investments such as fertilizer because they were concerned that crops would be flooded. The Fe and Mn contents in samples could be used to indicate whether reduction of fertilizer investment was the main cause (Zhang, 2011, Zhao et al., 2007). The newly submerged area was flooded at 160-170 m elevation between October and May, a period during which the mean temperature was about $10.7^{\circ} \mathrm{C}$, and microbial activity was low, which may reduce the risk of heavy metals in the newly submerged area.

\subsection{Identification of heavy metal sources in the surface soils}

There was a study showed that $\mathrm{Cd}, \mathrm{Co}, \mathrm{Ni}, \mathrm{Pb}, \mathrm{Cr}, \mathrm{Cu}, \mathrm{Se}, \mathrm{V}, \mathrm{Sb}$, and $\mathrm{Sr}$ concentrations have a uniform spatial distribution in the reservoir and all had low concentrations (Li et al., 2008). The Danjiangkou Reservoir has good water quality, which could easily be affected by the release of heavy metals from the newly submerged area. Therefore, the newly submerged area is a region of high potential risk for the reservoir water. Heavy metals in soils came from natural and man-made sources, the former mainly originate from natural geochemical processes, such 

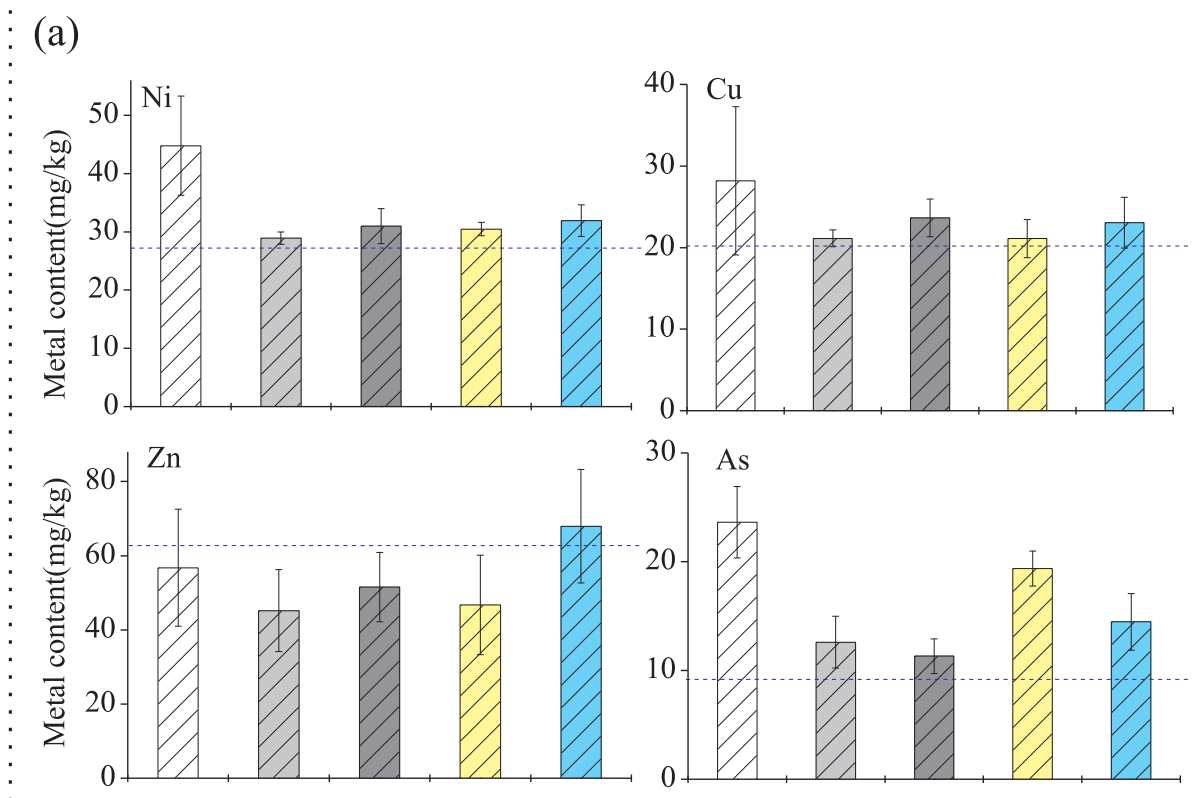

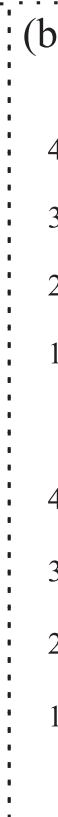

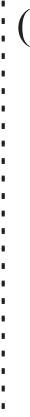

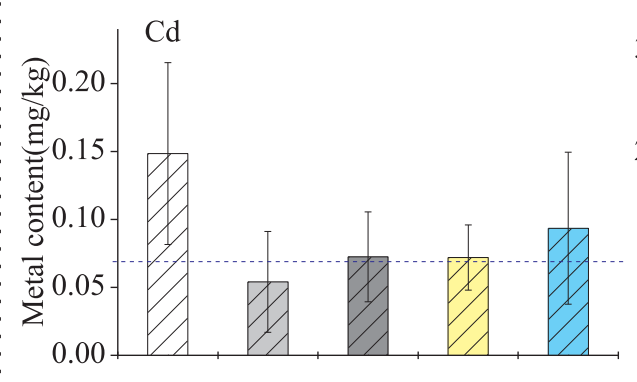
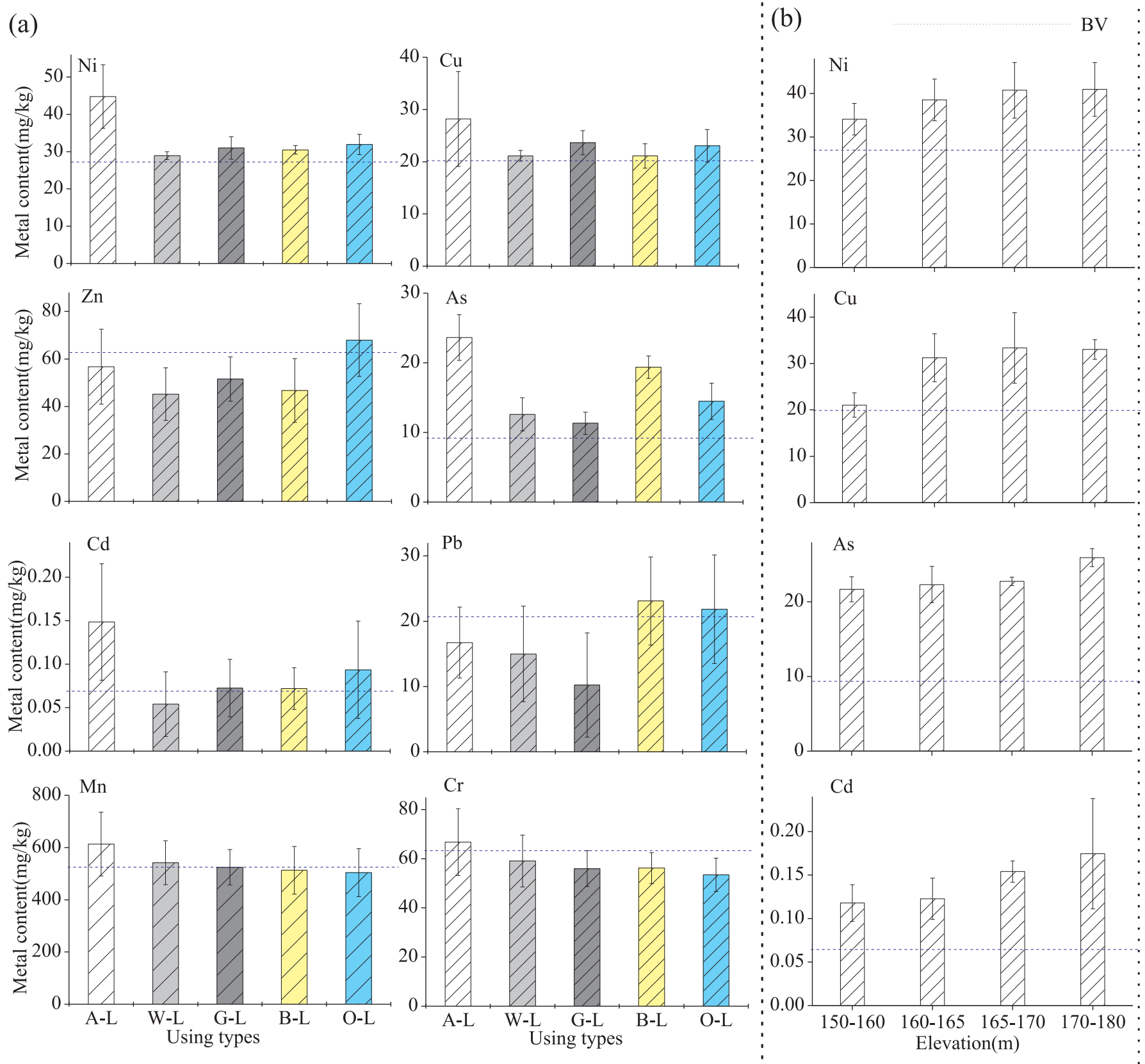

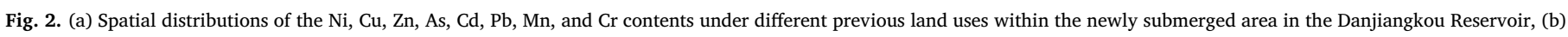

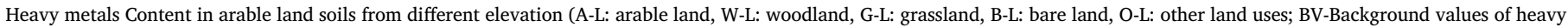
metals in Henan Province; $\mathrm{n}=92$ ).

as rock and mineral weathering, while the latter originate from industrial and agricultural production and domestic activities (Wei et al., 2016; Gao et al., 2016; Han et al., 2016). General metal mineral mining, smelting, waste incineration and landfill, fertilizer production and using pesticides could cause direct or indirect heavy metal contamination, leading to the eventual accumulation in the wider environment (Babek et al., 2015; Dung et al., 2013; Novakova et al., 2016). The $I_{g e o}$ method reflects the nature of the heavy metal distribution characteristics and allows us to distinguish the environmental impact by human activities. Human activities (such as fertilization and irrigation) will affect the soil heavy metal contents, and the $I_{\text {geo }}$ can be used to determine the influence of human activities on the soil heavy metal pollution (Weiss et al., 2008).

The heavy metals $I_{g e o}$ values are shown in Fig. 3(a). The proportion of $\mathrm{Ni}$ and $\mathrm{Cu}$ in the Danjiangkou Reservoir soils was not above 0, indicating that soils were generally not enriched. The $\mathrm{Zn}, \mathrm{Pb}, \mathrm{Mn}$ and $\mathrm{Cr}$ had the same source (mainly natural geochemical processes). The mean values $I_{\text {geo }}$ were above 0.5 for As and Cd, which indicated that the soils were moderately polluted.

The EF values were calculated to evaluate anthropogenic influences on heavy metals in surface soils of the study area (Li et al., 2010). The EF value above 1.5 suggests that anthropogenic processes have made a significant contribution to heavy metals in the area. As shown in Fig. 3(b), the EF value of As was highest in the newly submerged area, reaching 1.67 on average, and the mean EF values of heavy metals were below 1.5. This indicates that there is only a minor amount of heavy metal pollution in the studied area and a low degree of anthropogenic pollution for all heavy metals except As.

In addition, use of PLI values could help with public understanding of the quality of soils in different zones. As shown in Fig. 3(c), the PLI 

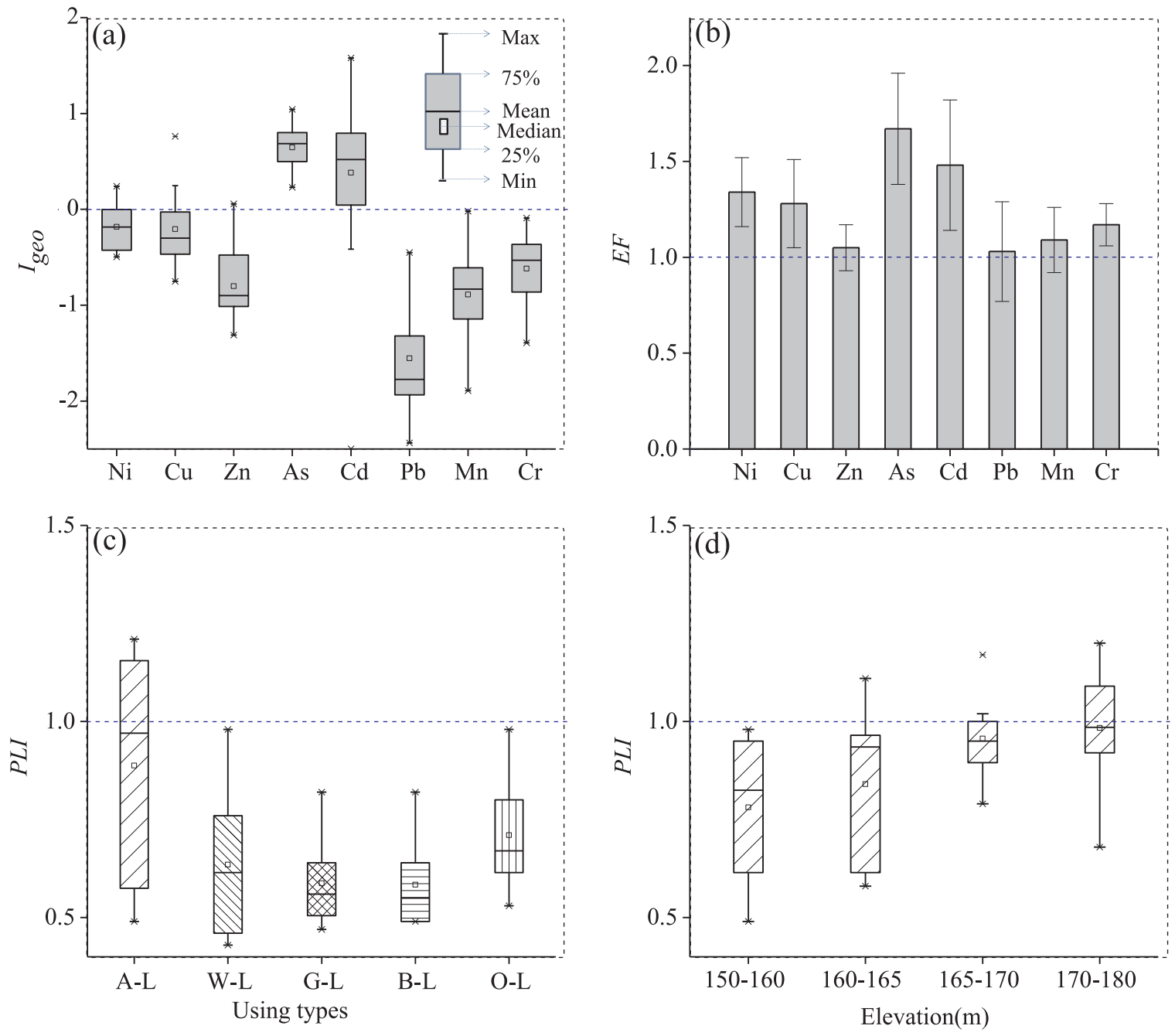

Fig. 3. Geo-accumulation index $\left(I_{\text {geo }}\right), \mathrm{EF}$, and PLI values for heavy metals of the newly submerged area in the Danjiangkou Reservoir $(\mathrm{n}=92)$.

values ranged from 0.46 to 1.21 , and the mean value was 0.62 in the newly submerged area. We found that $4.32 \%$ of PLI values exceeded 1 , which were mainly in arable land, indicating that most of the area's surface soil was not contaminated with the investigated heavy metals. Evaluation of all land-use types showed that soil contamination by heavy metals decreased in the following order: arable land $>$ others $>$ woodland $>$ grassland $>$ bare land. The average PLI values in arable land at $150-160,160-165,165-170$, and 170-180 m elevation were $0.64,0.71,0.94$ and 0.98 , respectively, as shown in Fig. 3(d). The heavy metal contamination was relatively higher in arable land above 160 m elevation.

The relationships between the different heavy metals contents in the newly submerged area of Danjiangkou Reservoir were analyzed using Pearson correlation coefficients (Table 3). The Ni contents correlated significantly with $\mathrm{Cu}(r=0.84, P<0.05)$, $\mathrm{Zn}(r=0.76, P<0.05)$, As $(r=0.52, P<0.05), \mathrm{Pb}(r=0.32, P<0.05)$, and $\mathrm{Mn}(r=0.35$, $P<0.05)$. The $\mathrm{Cu}$ contents were well correlated with $\mathrm{Zn}, \mathrm{As}, \mathrm{Pb}$ and $\mathrm{Mn}$, which indicated these metals are commonly associated with similar human activities, especially phosphate fertilizer use. Moreover, according to Weng's ratio, $\mathrm{Zn}, \mathrm{Cu}$, and $\mathrm{Pb}$ have a similar conservative behavior in the environment, and have similar geochemical properties (Devesa-Rey et al., 2013; Weng et al., 2003). The Cr contents did not correlate well with the other metals in samples, indicating that $\mathrm{Cr}$ contamination in the newly submerged area might have different origins from the other metals. In all samples, significant negative correlations $(P<0.05)$ were found between $\mathrm{Cd}$ and $\mathrm{Pb}$ or $\mathrm{Mn}$, indicating that the spatial distributions of these metals originated from similar sources.
Table 3

Pearson correlation coefficients for the relationships between the heavy metal contents analyzed in samples from newly submerged areas.

\begin{tabular}{|c|c|c|c|c|c|c|c|c|}
\hline & $\mathrm{Ni}$ & $\mathrm{Cu}$ & $\mathrm{Zn}$ & As & Cd & $\mathbf{P b}$ & Mn & $\mathrm{Cr}$ \\
\hline $\mathrm{Ni}$ & 1 & & & & & & & \\
\hline $\mathrm{Cu}$ & $0.84\left(^{(1+x)}\right)$ & 1 & & & & & & \\
\hline $\mathrm{Zn}$ & $0.76\left(^{(t)}\right)$ & $0.89\left(^{(* \pi)}\right)$ & 1 & & & & & \\
\hline As & $0.52(" *)$ & $0.42\left(^{* * *}\right)$ & $\left.0.37{ }^{* *}\right)$ & 1 & & & & \\
\hline Cd & 0.08 & 0.11 & 0.11 & -0.001 & 1 & & & \\
\hline $\mathrm{Pb}$ & $0.32(" *)$ & $0.38\left(^{(* *}\right)$ & $0.37\left({ }^{* *}\right)$ & 0.04 & $-0.34\left({ }^{* * 1}\right)$ & 1 & & \\
\hline Mn & $0.35\left(^{(t+1)}\right)$ & $0.32(")$ & 0.23 & 0.03 & -0.28() & $0.53\left(^{* *}\right)$ & $0.38(" * a)$ & \\
\hline $\mathrm{Cr}$ & 0.07 & 0.14 & -0.03 & 0.13 & $0.25(")$ & -0.19 & $0.94\left(^{* \prime \prime}\right)$ & 1 \\
\hline
\end{tabular}

$* P<0.05:$ *Correlation significant at the 0.05 level (2-tailed).

$* * P<0.01: * *$ Correlation significant at the 0.01 level (2-tailed), $\mathrm{n}=92$.

According to $I_{g e o}$ and EF values they were mainly from natural geochemical sources. In contrast, $\mathrm{Ni}, \mathrm{Cd}$, As, and $\mathrm{Cu}$ were mainly attributed to anthropogenic sources.

\subsection{Risk and toxicity assessment of heavy metals in the surface soils}

The PER method was developed to assess ecological risk for aquatic pollution control, based on the sensitivity of the aquatic system (Kucuksezgin et al., 2008). It was also used to assess the heavy metals in the newly submerged area of the Danjiangkou Reservoir, and reveal the degree of pollution to the freshwater ecosystem. The PER index of an individual element $\left(E_{r}^{i}\right)$ and the comprehensive PER index $(R I)$ of heavy 

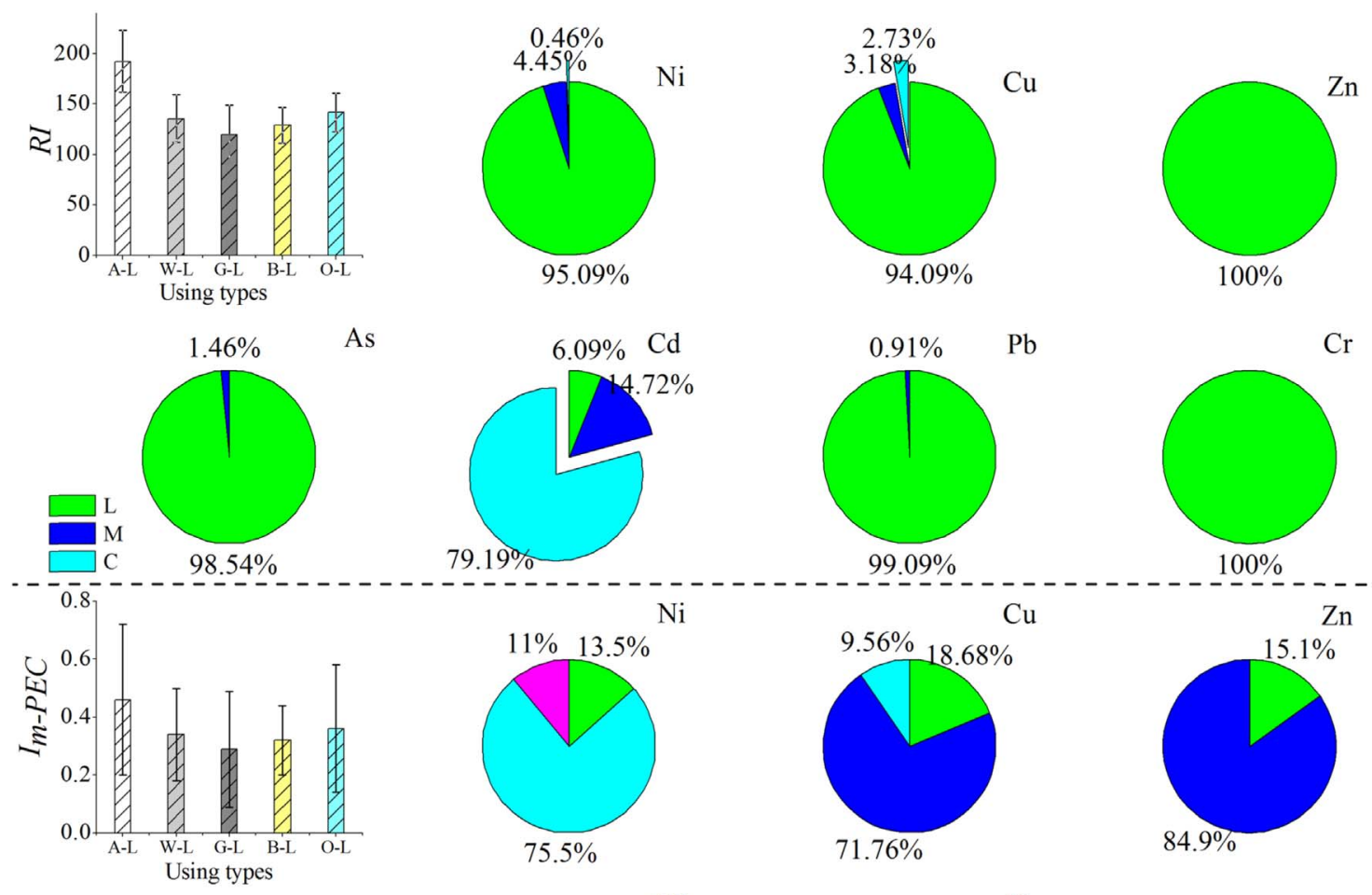

$6.09 \% \mathrm{Cd}$
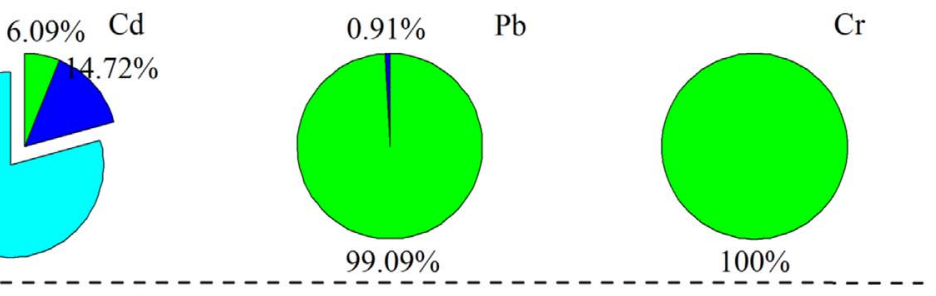

$\mathrm{Cu}$

$\mathrm{Zn}$
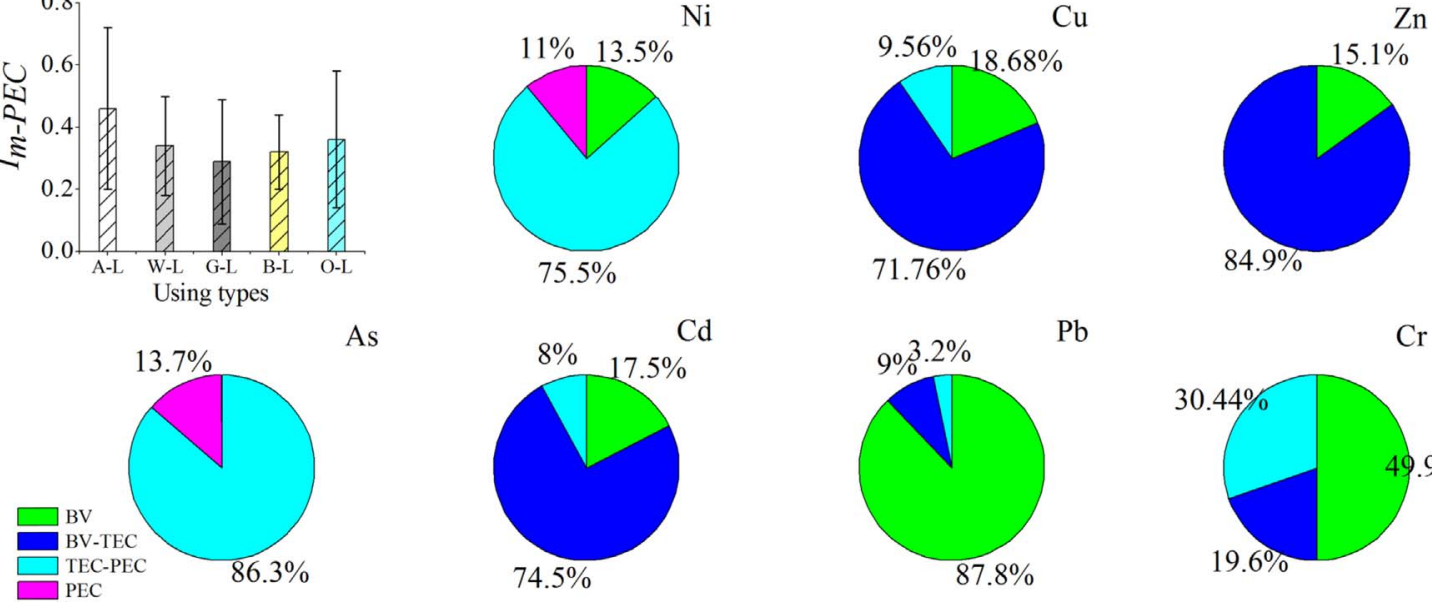

As
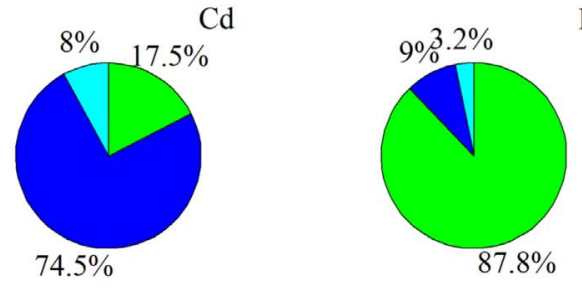

$\mathrm{Pb}$

$\mathrm{Cr}$

Fig. 4. $Q_{m-P E C}$ and $R I$ in different using type land of the newly submerged area in the Danjiangkou Reservoir $(\mathrm{n}=92)$.

metals in the Danjiangkou Reservoir were calculated, as shown in Fig. 4. Taking the geochemical background values as reference, the results indicated that there was almost no risk in newly submerged areas. The $E_{r}^{i}$ values of $\mathrm{Ni}, \mathrm{Cu}, \mathrm{Zn}, \mathrm{As}, \mathrm{Pb}$, and $\mathrm{Cr}$ were all lower than 40 , belong to "low ecological risk" category. However, the $E_{r}^{i}$ for Cd was 124.61 and $79.19 \%$ of the samples reached "considerable risk" status. The $R I$ value was 160.44 at the "moderate risk" level. The $R I$ of arable land was 192.18, the highest of all the land-use types, and the grassland was lowest at 98.2. The mean values of $I_{g e o}$ for As and Cd were higher than other metals, because the As biological toxicity factor was 10 and $\mathrm{Cd}$ was 30 . Therefore, the prevention and treatment of $\mathrm{Cd}$ accumulation in the newly submerged area, and reduction of its environmental risks, should become an important goal of the environmental management and risk control in the Danjiangkou Reservoir.

Threshold effect concentration (TEC), probable effect concentration (PEC), and background value (BV) for the studied heavy metals and the comparison with metal contents in this study are shown in Table S4, which were all based on previous studies (Ma et al. 2013). The $Q_{m-P E C}$ values can be used as an index of sediment toxicity associated with the studied heavy metals. $Q_{m-P E C}$ value $>0.5$ indicates that adverse effects on organisms are likely, while the $Q_{m-P E C}$ value $<0.5$ indicates that the surface sediment is not toxic to organisms. In this study, the $Q_{m-P E C}$ values ranged from 0.09 to 0.78 , with an average of 0.35 and the arable land was 0.46 higher than other land uses. The mean $Q_{m-P E C}$ of the newly submerged area in the Danjiangkou Reservoir was not more than 0.50 , which indicates that the area was not toxic and only slightly contaminated. It is likely that this low-level contamination mainly originated from fertilizer use. As shown in Fig. 4, single element toxicity assessment revealed that As had potential risks to exert biological toxic effects in the newly submerged area. The As contents exceeding the PEC was $13.7 \%$ for the soil samples. The Ni and $\mathrm{Cr}$ contents in most of the newly submerged area exceeded the TEC in $75.5 \%$ and $59.04 \%$ samples, respectively. However, Cd contents in $92 \%$ of samples and $\mathrm{Pb}$ contents in $96.8 \%$ of samples were lower than the TEC, which indicates that $\mathrm{Cd}$ and $\mathrm{Pb}$ represented almost no risk of harm to benthic organisms in the area. Those findings were consistent with the results of the $I_{g e o}$ analysis.

In addition, some researchers have considered the effect of dissolved oxygen concentration on potential metal releasing and accumulation, and found that the increasing of dissolved oxygen concentration could enhance the mobility of heavy metals. The newly submerged areas of Danjiangkou Reservoir are submerged by water in every winter, and the water-soil interface could become anaerobic environment. Moreover, the temperature is usually low in winter, so the potential release risk of heavy metals in the soils is likely to be lower than assessed. Thus, to more accurately evaluate heavy metal pollution and toxicity, subsequent research should combine assessment of the contents and bioavailability of heavy metals, which would be useful in developing management strategies on controlling heavy metal pollution.

\section{Conclusions}

In this study, we measured the heavy metals contents in the newly submerged area of the Danjiangkou Reservoir. We observed high $\mathrm{Ni}$, $\mathrm{Cu}, \mathrm{As}$, and $\mathrm{Cd}$ contents in the samples. Moreover, the mean $I_{\text {geo }}$ values for As and Cd were above 0.5 , indicated that the soils were moderately polluted. Only $\mathrm{Ni}$ and $\mathrm{Cu}$ had $I_{\text {geo }}$ values below 0 in the soils; the mean values of $I_{g e o}$ for $\mathrm{Zn}, \mathrm{Pb}, \mathrm{Mn}$ and $\mathrm{Cr}$ were all more than 0 . Examination 
of heavy metal contents under different previous land using types indicated that arable land was strongly affected by anthropogenic sources and higher contamination than other types of land, especially above $160 \mathrm{~m}$ elevation. The mean values of EF indicated only minor heavy metal pollution in the studied area and a low degree of anthropogenic pollution for all detected heavy metals except As. Only a few PLI values exceeded 1 in arable land, and most soils samples in the study area were not contaminated with the investigated heavy metals. We also used PER to assess the degree of ecological risk in this study. The $E_{r}^{i}$ values of $\mathrm{Ni}$, $\mathrm{Cu}, \mathrm{Zn}, \mathrm{As}, \mathrm{Pb}$, and $\mathrm{Cr}$ all belong to the "low ecological risk" level, the $T_{r}^{i}$ of $\mathrm{Cd}$ reached the "considerable risk" level, and $R I$ value was at the "moderate risk" level. On the whole, there was almost no threatening the water quality of Danjiangkou Reservoir by the heavy metals in soils of newly submerged areas.

\section{Acknowledgments}

This research was supported by the Youth Innovation Promotion Association CAS (Wenzhong Tang, 2017059) and the One-Three-Five Program of the Research Center for Eco-Environmental Sciences (No. YSW2013B02). We also acknowledge the support received by Wenzhong Tang from the Chinese Scholarship Council (CSC Grant 201604910224).

\section{Appendix A. Supplementary material}

Supplementary data associated with this article can be found in the online version at http://dx.doi.org/10.1016/j.ecoenv.2017.06.050.

\section{References}

Bian, Y., Ouyang, T., Zhu, Z., Huang, N., Wan, H., Li, M., 2014. Magnetic properties of agricultural soil in the Pearl River Delta, South China - Spatial distribution and influencing factor analysis. J. Appl. Geophys. 107, 36-44.

Boughriet, A., Proix, N., Billon, G., Recourt, P., Ouddane, B., 2007. Environmental impacts of heavy metal discharges from a smelter in Deule-canal sediments (Northern France): concentration levels and chemical fractionation. Water A Soil Pollut. 180, 83-95.

Babek, O., Grygar, T.M., Famera, M., Hron, K., Novakova, T., Sedlacek, J., 2015. Geochemical background in polluted river sediments: how to separate the effects of sediment provenance and grain size with statistical rigour? Catena 135, 240-253.

Campanha, M.B., Moreira, A.B., Bisinoti, M.C., 2012. Metal fluxes at the sediment-water interface in rivers in the Turvo/Grande drainage basin, So Paulo state, Brazil. J. Soils Sediments 12, 1508-1516.

Devesa-Rey, R., Iglesias, M.L., Perez, R., Diaz, F.F., Barral, M.T., 2013. Application of the Weng's ratio for the identification of $\mathrm{Zn}, \mathrm{Cu}$, and $\mathrm{Pb}$ contamination in soils and sediments. J. Soils Sediments 13, 932-942.

Dung, T.T.T., Cappuyns, V., Swennen, R., Phung, N.K., 2013. From geochemical background determination to pollution assessment of heavy metals in sediments and soils. Rev. Environ. Sci. Biol. Technol. 12, 335-353.

Gao, B., Han, L., Hao, H., 2016. Pollution characteristics of mercury (Hg) in surface sediments of major basins, China. Ecol. Ind. 67, 577-585.

Gao, B., Zhou, H., Liang, X., Tu, X., 2013. Cd isotopes as a potential source tracer of metal pollution in river sediments. Environ. Pollut. 181, 340-343.

Håkanson, L., 1980. An ecological risk index for aquatic pollution control: a sedimentological approach. Water Res. 14, 975-1001.

Hu, H., Jin, Q., Kavan, P., 2014. A study of heavy metal pollution in China: current status, pollution-control policies and countermeasures. Sustainability 6, 5820-5838.

Han, L.F., Gao, B., Yang, Z., Xu, D.Y., 2016. Comprehensive assessment of seldom monitored trace elements pollution in the riparian soils of the Miyun Reservoir, China Environ. Sci. Pollut. Res. 23, 20772-20782.

Kucuksezgin, F., Uluturhan, E., Batki, H., 2008. Distribution of heavy metals in water, particulate matter and sediments of Gediz River (Eastern Aegean). Environ. Monit. Assess. 141, 213-225.

Li, C., Li, F., Wu, Z., Cheng, J., 2015. Effects of landscape heterogeneity on the elevated trace metal concentrations in agricultural soils at multiple scales in the Pearl River Delta, South China. Environ. Pollut. 206, 264-274.

Li, S., Zhang, Q., 2010. Risk assessment and seasonal variations of dissolved trace elements and heavy metals in the Upper Han River, China. J. Hazard. Mater. 181, 1051-1058.

Li, S.Y., Xu, Z.F., Cheng, X.L., Zhang, Q.F., 2008. Dissolved trace elements and heavy metals in the Danjiangkou Reservoir, China. Environ. Geol. 55, 977-983.

Müller, G., 1969. Index of geoaccumulation in sediments of the Rhine River. Geojournal 2, 108-118.

Novakova, T., Grygar, T.M., Kotkova, K., Elznicova, J., Strnad, L., Mihaljevic, M., 2016. Pollution assessment using local enrichment factors: the Berounka River (Czech Republic). J. Soils Sediments 16, 1081-1092.

Sakellari, A., Plavsic, M., Karavoltsos, S., Dassenakis, M., Scoullos, M., 2011. Assessment of copper, cadmium and zinc remobilization in Mediterranean marine coastal sediments. Estuar. Coast. Shelf Sci. 91, 1-12.

Selvaraj, K., Mohan, V.R., Szefer, P., 2004. Evaluation of metal contamination in coastal sediments of the Bay of Bengal, India: geochemical and statistical approaches. Mar. Pollut. Bull. 49, 174-185.

Tang, W.Z., Shan, B.Q., Zhang, H., Zhang, W.Q., Zhao, Y., 2014. Heavy metal contamination in the surface sediments of representative limnetic ecosystems in Eastern China. Sci. Rep. 4, 7152.

Tomlinson, D.L., Wilson, J.G., Harris, C.R., Jeffrey, D.W., 1980. Problems in the assessment of heavy-metal levels in estuaries and the formation of a pollution index. Helg. Mar. Res. 33, 566-575.

Tang, W.Z., Mao, Z.P., Zhang, H., Shan, B.Q., Zhao, Y., Ding, Y.K., 2015. Water resources: the prerequisite for ecological restoration of rivers in the Hai River Basin, Northern China. Environ. Sci. Polut. Res. 22, 1359-1365.

Wang, J., Yin, W., Qiang, X.Y., 2015. The potential risk evaluation of farmland soil from new submerged area in Danjiangkou Reservoir. China Environ. Sci. 35 (1), 157-164.

Wei, X., Han, L.F., Gao, B., 2016. Distribution, bioavailability, and potential risk assessment of the metals in tributary sediments of Three Gorges Reservoir: the impact of water impoundment. Econ. Ind. 61, 667-675.

Weiss, D.J., Rehkamper, M., Schoenberg, R., McLaughlin, M., Kirby, J., Campbell, P.G.C., Arnold, T., Chapman, J., Peel, K., Gioia, S., 2008. Application of nontraditional stable-isotope systems to the study of sources and fate of metals in the environment. Environ. Sci. Technol. 42, 655-664.

Weng, H.X., Zhang, X.M., Chen, X.H., Wu, N.Y., 2003. The stability of the relative content ratios of $\mathrm{Cu}, \mathrm{Pb}$ and $\mathrm{Zn}$ in soils and sediments. Environ. Geogr. 45, 79-85.

Yu, K.C., Tsai, L.J., Chen, S.H., Ho, S.T., 2001. Chemical binding of heavy metals in anoxic river sediments. Water Res. 35, 4086-4094.

Zhu, X.L., Shan, B.Q., Tang, W.Z., Li, S.S., Rong, N., 2015. Distributions, fluxes, and toxicities of heavy metals in sediment pore water from tributaries of the Ziya River system, northern China. Environ. Sci. Pollut. Res. 23, 5516-5526.

Zhang, L., Wen, Q., Qin, Y.W., 2015. Concentrations, sources and ecological risk evaluation of polycyclic aromatic hydrocarbons (PAHs) in the soil of relocation areas from the Danjiangkou reservoir. Res. Environ. Sci. 28 (5), 767-774.

Zeng, Z.X., Lei, P., Zhang, H., 2015. Nitrogen and phosphorus fractions and releasing characteristics of the soils from the representative water-levelfluctuating zone of Danjiangkou reservoir. Acta Sci. Circum. 35 (5), 1383-1392.

Zhang, C.M., 2011. Analysis and evaluation of available Zn, Mn, Cu and Fe contents of topsoil in Gulang irrigation region. Pratac. Sci. 28 (6), 1221-1225.

Zhao, M., Cai, K., Zhao, Z.Y., 2007. Effect of organic manure on the content of available $\mathrm{Cu}, \mathrm{Zn}, \mathrm{Fe}$ and $\mathrm{Mn}$ in soil. J. Soils Sci. 38 (1), 93-96. 